\title{
Galectin-15 in ovine uteroplacental tissues
}

\author{
C Allison Gray ${ }^{1}$, Kathrin A Dunlap ${ }^{1}$, Robert C Burghardt ${ }^{2}$ and Thomas E Spencer ${ }^{1}$ \\ ${ }^{1}$ Center for Animal Biotechnology and Genomics and Department of Animal Science and ${ }^{2}$ Department of \\ Veterinary Integrative Biosciences, Texas A\&M University, College Station, TX 77843, USA
}

Correspondence should be addressed to TE Spencer; Email: tspencer@tamu.edu

\begin{abstract}
Galectin-15 is the newest member of a secreted $\beta$-galactoside-binding lectin family. The galectin-15 gene is expressed specifically by the endometrial luminal epithelium (LE) and superficial ductal glandular epithelium (sGE) of the ovine uterus. The proposed extracellular role of secreted galec 7 tin-15 is to regulate implantation and placentation by functioning as a heterophilic cell adhesion molecule between the conceptus trophectoderm and endometrial LE, while that of intracellular galectin15 is to regulate cell survival, differentiation and function. The present study determined galectin-15 expression in uteroplacental tissues during gestation and in the postpartum uterus. In the uterine lumen, secreted galectin-15 was found as multimers, particularly on days 14 and 16 of pregnancy. In the endometrial epithelium and conceptus trophectoderm, intracellular galectin-15 protein was found associated with crystalline structures. Between days 20 and 120 of pregnancy, galectin-15 mRNA was expressed specifically by the LE and sGE of the intercaruncular endometrium of ewes. Immunoreactive galectin-15 protein was most abundant in the trophectoderm with lower levels in the endometrial LE and sGE. Galectin-15 protein was detected in allantoic fluid, but not in amniotic fluid. After parturition, galectin-15 mRNA declined in the endometrium from postpartum day (PPD) 1 to 28 and exhibited a variegated expression pattern in the LE and sGE. These results indicate that galectin-15 is synthesized and secreted throughout gestation by the endometrial LE/sGE and is absorbed by the placenta and forms crystals within the trophectoderm, whereas the remainder is cleared into the allantois after being transported into the fetal circulation via the placental areolae. Based on the biological properties of other galectin family members, galectin-15 is hypothesized to have biological roles in conceptus-endometrial interactions, uterine immune and inflammatory responses, and placental morphogenesis and function.
\end{abstract}

Reproduction (2005) $130231-240$

\section{Introduction}

The endometrium of the uterus synthesizes and secretes or selectively transports a variety of substances, collectively termed the histotroph, necessary for conceptus (embryo/fetus and associated placental membranes) survival, growth and implantation in mammals (Bazer 1975, Roberts \& Bazer 1988, Fazleabas et al. 1997, Kane et al. 1997, Carson et al. 2000). Histotroph is a rather undefined, complex mixture of adhesion proteins, transport proteins, ions, growth factors, hormones, proteases, protease inhibitors, amino acids and other molecules (Bazer 1975, Roberts \& Bazer 1988). Uterine secretions are of particular importance for conceptus survival and growth in domestic animals due to their protracted peri-implantation period and non-invasive types of placentation (Bazer 1975, Roberts et al. 1987, Roberts \& Bazer 1988). Indeed, histotroph is absorbed by the placenta, transported into the fetal circulation and cleared by the kidney into the allantois via the urachus (Bazer 1975, Roberts \&
Bazer 1988). Although the allantois was traditionally considered to be a reservoir for fetal wastes (Alexander \& Williams 1968), studies in the pig and sheep support the idea that components of allantoic fluid have an important role in fetal nutrition (Bazer 1989). Analysis of recurrent pregnancy loss in the uterine gland-knockout ewe model indicates that histotroph emanating from the endometrial luminal epithelium (LE) and glandular epithelium (GE) is clearly required for peri-implantation conceptus survival and growth in sheep (Gray et al. 2001, 2002). However, uterine histotroph is hypothesized to remain important for conceptus growth and development throughout gestation as a complement to hematrophic nutrition derived from increased uterine blood flow through placentomes.

Recently, a new galectin family member and component of uterine histotroph, galectin-15, was discovered in the endometrium of sheep (Gray et al. 2004). Galectin-15 was originally identified in ovine intestinal epithelium as being induced in response to infection by Haemonchus contortus, a nematode parasite (Dunphy et al. 2000). Expression 
of the galectin-15 gene was detected only after day 10 of pregnancy in the endometrial LE and superficial ductal GE (sGE) and was induced by progesterone and further stimulated by interferon $\tau$, the pregnancy-recognition signal produced by the conceptus. In the endometrium, galectin-15 protein had a nucleocytoplasmic distribution within the LE and SGE and was also concentrated near and on the apical surface. Further, secreted galectin-15 protein was abundant in the histotroph recovered from the uterine lumen and was immunologically similar to the previously unknown $14 \mathrm{kDa}$ protein that is a component of crystals in the endometrial epithelium and conceptus trophectoderm (Gray et al. 2004, Kazemi et al. 1990). Galectins bind $\beta$-galactosides and functionally crosslink glycoprotein and glycolipid receptors on the surface of cells, which initiates biological responses that include cell proliferation, differentiation, motility, adhesion and apoptosis (Cooper 2002, Yang \& Liu 2003, Liu \& Rabinovich 2005). The temporal and spatial alterations in galectin-15 mRNA and protein the uterine endometrial epithelia and lumen during the peri-implantation period of early pregnancy, combined with the known biological activities of other galectins, make it a strong candidate mediator of conceptus-endometrial interactions during implantation (Gray et al. 2004). One proposed extracellular role of galectin-15 in the uterine lumen is to functionally bind and crosslink $\beta$-galactosides on glycoproteins and glycolipids, thereby allowing it to function as a heterophilic cell adhesion molecule bridging the conceptus trophectoderm and the endometrial LE and stimulating biological responses within the trophoblast, such as migration, proliferation and differentiation, which are critical for successful conceptus implantation (Spencer et al. 2004).

Our working hypothesis is that galectin-15 is secreted as a component of histotroph that is secreted by the endometrial epithelia throughout pregnancy in sheep. Therefore, the present study investigated: (1) extracellular and intracellular galectin-15 protein in the uterus and conceptus on days 12 to 16 of pregnancy; (2) galectin-15 mRNA and protein in uteroplacental tissues between days 20 and 120 of pregnancy; and (3) galectin-15 mRNA in the uterus after parturition.

\section{Materials and Methods}

\section{Animals and tissue collection}

Experimental and surgical procedures on crossbred Suffolk sheep (Ovis aries) complied with the Guide for Care and Use of Agriculture Animals in Teaching and Research, and were approved by the Institutional Animal Care and Use Committees of Texas A\&M University.

\section{Study 1}

Cyclic ewes were mated at estrus (day 0) to either a vasectomized or an intact ram and were hysterectomized
( $n=5$ sheep/day) on days 12,14 or 16 of the estrous cycle or on days 12, 14 and 16 of pregnancy (the gestation period is 147 days). For all surgeries performed, ewes were administered isofluorane (5\%) via an inhalation mask to induce anesthesia, which was maintained with isofluorane $(1-5 \%)$. A midventral laparotomy was performed to expose the reproductive tract. The uterine lumen was flushed with saline and examined for the presence of a morphologically normal conceptus to confirm pregnancy. Uterine flushes were clarified by centrifugation (3000 $\mathrm{g}$ for $30 \mathrm{~min}$ at $4{ }^{\circ} \mathrm{C}$ ), aliquoted and frozen at $-80^{\circ} \mathrm{C}$. Cross-sections of the uterine horn ipsilateral to the ovary bearing the corpus luteum and conceptuses from day 16 pregnant ewes were fixed for analysis by electron microscopy.

\section{Study 2}

As described previously (Kwon et al. 2004), ewes were mated to rams of proven fertility at estrus and 12 and $24 \mathrm{~h}$ later. Ewes were assigned randomly to be hysterectomized ( $n=4$ per day) on day 20,40,60, 80, 100 or 120 of gestation to allow collection of uteroplacental tissues and fetal fluids. At hysterectomy, samples of the amniotic and allantoic fluids were collected, snap-frozen in liquid nitrogen and stored at $-80^{\circ} \mathrm{C}$. Total endometrium was collected on days 16 and 20 of pregnancy, whereas caruncular and intercaruncular endometria were dissected from the myometrium collected between days 40 and 120 of gestation. Portions of these tissues were snap-frozen in liquid nitrogen and stored at $-80^{\circ} \mathrm{C}$. Sections of the uterine wall with the attached trophectoderm were also fixed in freshly prepared $4 \%(\mathrm{w} / \mathrm{v})$ paraformaldehyde in PBS $(\mathrm{pH}$ 7.2) or embedded in Optimal Cutting Temperature (OCT) compound (Miles, Oneota, NY, USA), snap-frozen in liquid nitrogen and stored at $-80^{\circ} \mathrm{C}$.

\section{Study 3}

As described previously (Gray et al. 2003), multiparous 5-8-year-old ewes were bred with rams of proven fertility, and pregnancy was determined by transabdominal ultrasonography. Ewes were assigned randomly to be ovariohysterectomized on postpartum days (PPD) 1, 7, 14 or 28 ( $n=4$ or 5 ewes/day). Ewes were checked twice daily for signs of labor or parturition. At hysterectomy, the residual placentomal or caruncular and intercaruncular areas of the uterine wall were dissected from the uteri of ewes on PPDs 1,7 or 14 , and sections $(\sim 1 \mathrm{~cm})$ were fixed in $4 \%$ $(\mathrm{w} / \mathrm{v})$ paraformaldehyde. On PPD 28, sections from the mid-portion of each uterine horn were fixed in $4 \%(\mathrm{w} / \mathrm{v})$ paraformaldehyde.

After $24 \mathrm{~h}$, fixed tissues from all studies were dehydrated through a graded series of ethanol solutions and embedded in Paraplast Plus (Oxford Labware, St Louis, $\mathrm{MO}$, USA) for histological analyses. 


\section{Western-blot analyses}

Uterine flushes from study 1 were concentrated using Centricon-3 columns (Amicon, Beverly, MA, USA). Protein content of concentrated flushes (study 1 ) and fetal fluids (study 2) was determined using a Bradford protein assay (Bio-Rad, Hercules, CA, USA) with BSA as the standard. For study 1 , uterine flush proteins $(20 \mu \mathrm{g})$ were separated by non-denaturing/non-reducing 12\% PAGE. For study 2, allantoic and amniotic fluid proteins $(20 \mu \mathrm{g})$ were denatured and separated by $15 \%$ SDS/PAGE. Western-blot analyses of separated protein was conducted as described previously (Spencer et al. 1999a) using enhanced chemiluminescence detection. Immunoreactive galectin-15 was detected using primary rabbit anti-ovine galectin-15 serum (provided kindly by Dr Els N T Meeusen, Monash University, Melbourne, Australia; Dunphy et al. 2000) at a 1:2500 dilution. Negative control blots were performed in which primary antibody was replaced by rabbit serum at the same concentration.

\section{Transmission electron microscopy (TEM)}

Endometrium and conceptuses from day 16 of gestation (study 1 ) were fixed in a solution of $2 \%$ paraformaldehyde $/ 3 \%$ glutaraldehyde in $0.08 \mathrm{M}$ sodium cacodylate $(\mathrm{pH}$ 7.2). After fixation, tissues were dehydrated in a gradient of $10-100 \%$ ethanol and embedded in Unicryl resin (SPI Supplies, West Chester, PA, USA). Routine staining of semi-thick sections with $0.1 \%$ Toluidine Blue and $1 \%$ sodium borate (Borax; $\mathrm{Na}_{2} \mathrm{~B}_{4} \mathrm{O}_{7} \cdot 10 \mathrm{H}_{2} \mathrm{O}$ ) was utilized to isolate areas of interest. Trimmed materials were then sectioned using an LKB ultramicrotome (type 4802A). The 70-90 nm-thick sections were stained with $10 \%$ uranyl acetate in $30 \%$ ethanol for 30 min followed by Reynolds' lead citrate for $10 \mathrm{~min}$ (Reynolds 1963). Sections were examined and photographed using a Zeiss 10CA transmission microscope at $80 \mathrm{kV}$ on Kodak electron microscope film 4489.

\section{Immunogold TEM}

Endometrium and conceptuses from day 16 of gestation (study 1) were fixed in 3\% paraformaldehyde and $0.2 \%$ glutaraldehyde in $0.1 \mathrm{M}$ cacodylate buffer $(\mathrm{pH} 7.2)$ containing $5 \%(\mathrm{w} / \mathrm{v})$ sucrose, dehydrated through ethanol, and embedded in Unicryl resin. Ultrathin sections were picked up on 300-hex nickel grids and floated on $10 \%$ heat-inactivated normal goat serum in $0.1 \%$ BSA/Tris for $30 \mathrm{~min}$. Grids were transferred to drops of rabbit antiovine galectin-15 serum (1:2000) or rabbit serum for $1 \mathrm{~h}$ at room temperature. After washing three times with $50 \mathrm{mM}$ Tris $(\mathrm{pH} 7.4)$ in $0.1 \%$ BSA for $1 \mathrm{~min}$ each, five times in $50 \mathrm{mM}$ Tris $(\mathrm{pH} \mathrm{7.4)}$ for 1 min each and twice in PBS for 5 min each, the grids were post-fixed in $2 \%$ glutaraldehyde in PBS for $5 \mathrm{~min}$ and rinsed with water. Grids were then dried at room temperature and stained lightly with uranyl acetate in $50 \%(\mathrm{v} / \mathrm{v})$ alcohol. TEM images were photographed as described above.

\section{RNA isolation and analyses}

Total cellular RNA was isolated from frozen intercaruncular and caruncular endometria from study 2 and intercaruncular endometrium from study 3 using the Trizol reagent (Gibco-BRL, Grand Island, NY, USA). For each ewe, denatured total cellular RNA $(20 \mu \mathrm{g})$ was analyzed by slot-blot hybridization using a radiolabeled antisense cRNA probe generated by in vitro transcription with $\left[\alpha-{ }^{32}\right.$ P]UTP (Amersham Pharmacia Biotech, Piscataway, NJ, USA) as described previously (Gray et al. 2004). Plasmid templates containing cDNAs for ovine galectin-15 (Gray et al. 2004) and 18 S rRNA (pT718S; Ambion, Austin, TX) were used to produce radiolabeled cRNA probes as described previously (Choi et al. 2001). Hybridization signals were detected by exposing washed slot blots to a phosphorimager screen and visualized and quantified using a Typhoon 8600 Variable Mode Imager (Molecular Dynamics, Sunnyvale, CA, USA).

\section{In situ hybridization}

Galectin-15 mRNA was localized in uterine tissue sections by in situ hybridization as described previously (Spencer et al. 1999b). Deparaffinized, rehydrated and deproteinated uterine sections $(5 \mu \mathrm{m})$ were hybridized with radiolabeled antisense or sense cRNAs generated from linearized ovine galectin-15 (Gray et al. 2004) plasmid templates using in vitro transcription with $\left[\alpha^{-35}\right.$ S]UTP. Autoradiographs of slides were prepared using Kodak NTB-2 liquid photographic emulsion. Slides were stored at $4{ }^{\circ} \mathrm{C}$ for 1 week as judged from autoradiographs, developed in Kodak D-19 developer, lightly counterstained with Gill's hematoxylin (StatLab, Lewisville, TX, USA), dehydrated through a graded series of alcohol to xylene, and coverslips affixed with Permount (Fisher Scientific, Atlanta, GA, USA

\section{Immunofluorescence analyses}

Proteins were localized in frozen intercaruncular and caruncular endometrial tissue sections $(8-10 \mu \mathrm{m})$ collected in study 2 by immunofluorescence staining as described previously (Johnson et al. 1999). Briefly, frozen tissues were sectioned $(8 \mu \mathrm{m})$ with a Hacker-Bright OTF cryostat (Hacker Instruments, Fairfield, NJ, USA) and mounted on Superfrost/Plus microscope slides (Fisher Scientific, Pittsburgh, PA, USA). Frozen sections were fixed in $-20^{\circ} \mathrm{C}$ methanol for $10 \mathrm{~min}$, permeabilized with $0.3 \%$ Tween-20 $(\mathrm{v} / \mathrm{v})$ in $0.02 \mathrm{M} \mathrm{PBS}$, and then blocked in antibody dilution buffer [two parts $0.02 \mathrm{M}$ PBS/ $1.0 \%$ BSA $(\mathrm{w} / \mathrm{v}) / 0.3 \%$ Tween-20 (w/v; pH 8.0) and one part glycerol] containing $5 \%$ normal goat serum $(\mathrm{v} / \mathrm{v})$ for $1 \mathrm{~h}$ at room temperature, and incubated overnight at $4{ }^{\circ} \mathrm{C}$ with the rabbit anti-ovine galectin-15 antibody (1:1000) or rabbit serum (1:1000). 
Immunoreactive protein was then detected using a fluorescein-conjugated secondary antibody for $1 \mathrm{~h}$ at room temperature. Slides were overlaid with Prolong antifade mounting reagent and then coverslips added (Molecular Probes, Eugene, OR, USA).

\section{Photomicroscopy}

Photomicrographs of in situ hybridization slides were taken using a Nikon Eclipse E1000 photomicroscope (Nikon Instruments, Melville, NY, USA). Digital images were captured using a Nikon DXM 1200 digital camera and assembled using Adobe Photoshop 7.0 (Adobe Systems, Seattle, WA, USA). For immunoflourescence analyses, representative fluorescence images were recorded using a Ziess Axioplan microscope (Carl Zeiss, Thornwood, NY, USA) equipped with a Hamamatsu chilled 3CCD color camera (Hamamatsu Photonics, Bridgewater, NJ, USA) using Adobe Photoshop 7.0 image-capture software. TEM negatives were converted to digital images using an Epson Perfection 3200 photo scanner (Epson America, Long Beach, CA, USA) and assembled using Adobe Photoshop 7.0.

\section{Statistical analyses}

All quantitative data were subjected to least-squares analysis of variance using the General Linear Models procedures of the Statistical Analysis System (Cary, NC, USA). Analyses of steady-state levels of endometrial mRNA determined by slot-blot hybridization included the $18 \mathrm{~S}$ rRNA as a covariate to correct for differences in sample loading. Least-squares regression analyses were used to determine effects of gestational or postpartum day on endometrial galectin-15 mRNA levels. In all analyses, error terms used in tests of significance were identified according to the expectation of the mean squares for error. Data are presented as least-squares means with overall S.E. values.

\section{Results}

\section{Galectin-15 in uterine flush and fetal fluids}

Western-blot analyses of uterine flushes from cyclic and pregnant ewes (study 1) revealed multimeric forms of immunoreactive galectin-15 protein separated by nondenaturing/non-reducing PAGE (Fig. 1). Although the predicted size of galectin-15 from the inferred amino acid sequence was only $15.5 \mathrm{kDa}$ (Gray et al. 2004), immunoreactive galectin-15 forms of $\sim 60$ and $80 \mathrm{kDa}$ were observed in the uterine flush of day 14 and 16 cyclic ewes and day 14 pregnant ewes. Interestingly, immunoreactive galectin-15 forms of $\sim 60,80$ and $100 \mathrm{kDa}$ were observed in the uterine flush of day 16 pregnant ewes. Multimeric forms of galectin-15 protein were only minimally present, or were absent, in the uterine flush of day 12 cyclic or pregnant ewes.

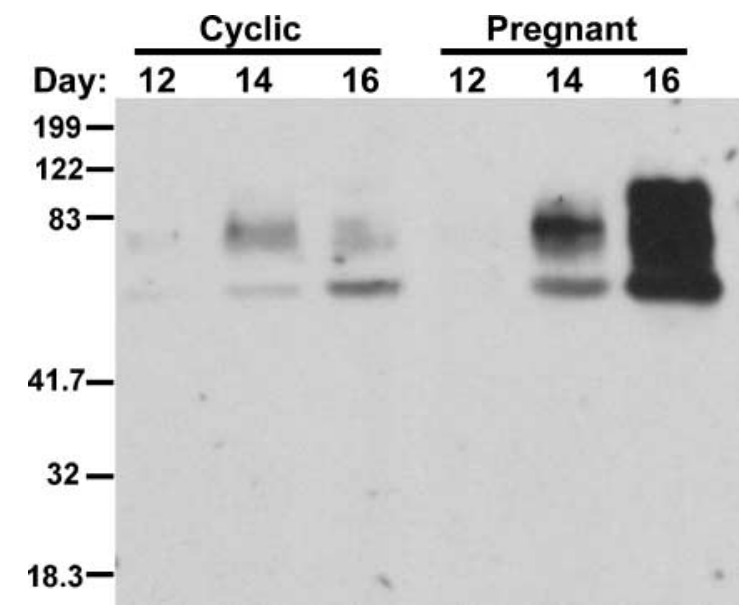

Figure 1 Analysis of immunoreactive galectin-15 protein in the uterine lumen of early pregnant ewes. Uterine flush proteins were separated under native conditions. Western-blot analyses found that immunoreactive galectin-15 was present as multimers of $\sim 60,80$ or $100 \mathrm{kDa}$. The predicted size of the galectin-15 monomer is $15.5 \mathrm{kDa}$. Positions of prestained molecular-mass standards $\left(\times 10^{-3}\right)$ are indicated on the left.

\section{TEM analysis of galectin-15 in the endometrium and conceptus trophectoderm}

Crystalline inclusion bodies were observed in both the endometrial LE (Fig. 2) and conceptus trophectoderm (Fig. 2) from day 16 pregnant ewes. These crystal structures were localized in the cytoplasm near the nucleus in the LE cells and were more abundant in the conceptus trophectodermal cells. The crystals appeared to be rhomboidal and were surrounded by a membrane. Immunogold labeling localized galectin-15 protein primarily to the crystalline inclusion bodies in both endometrial LE and conceptus trophectoderm.

\section{Galectin-15 mRNA and protein in uteroplacental tissues}

In pregnant ewes (study 2), steady-state levels of galectin15 mRNA were very low to undetectable in the caruncular endometrium (Fig. 3). Galectin-15 mRNA expression in the intercaruncular endometrium was lowest during early pregnancy from days 16 to 40, increased 3.5-fold between days 40 and 60 of pregnancy, and remained elevated to day 120 (quadratic effect of day, $P<0.001$ ).

Galectin-15 mRNA was observed specifically in the endometrial LE, if present, and $\mathrm{SGE}$, but not middle to deep GE, stroma, myometrium or placenta (Fig. 4). Between days 20 and 40 of pregnancy, galectin-15 mRNA was detected only in the SGE of the endometrium, because the LE was absent. During ovine placentation, the LE fuses with the trophoblast giant binucleate cells (BNCs) to form a syncytia beginning on day 16 when the BNCs differentiate (Wimsatt 1951, Wooding 1984). The LE reappears in the intercaruncular endometrial areas between days 40 and 60 . On day 60 and thereafter, 

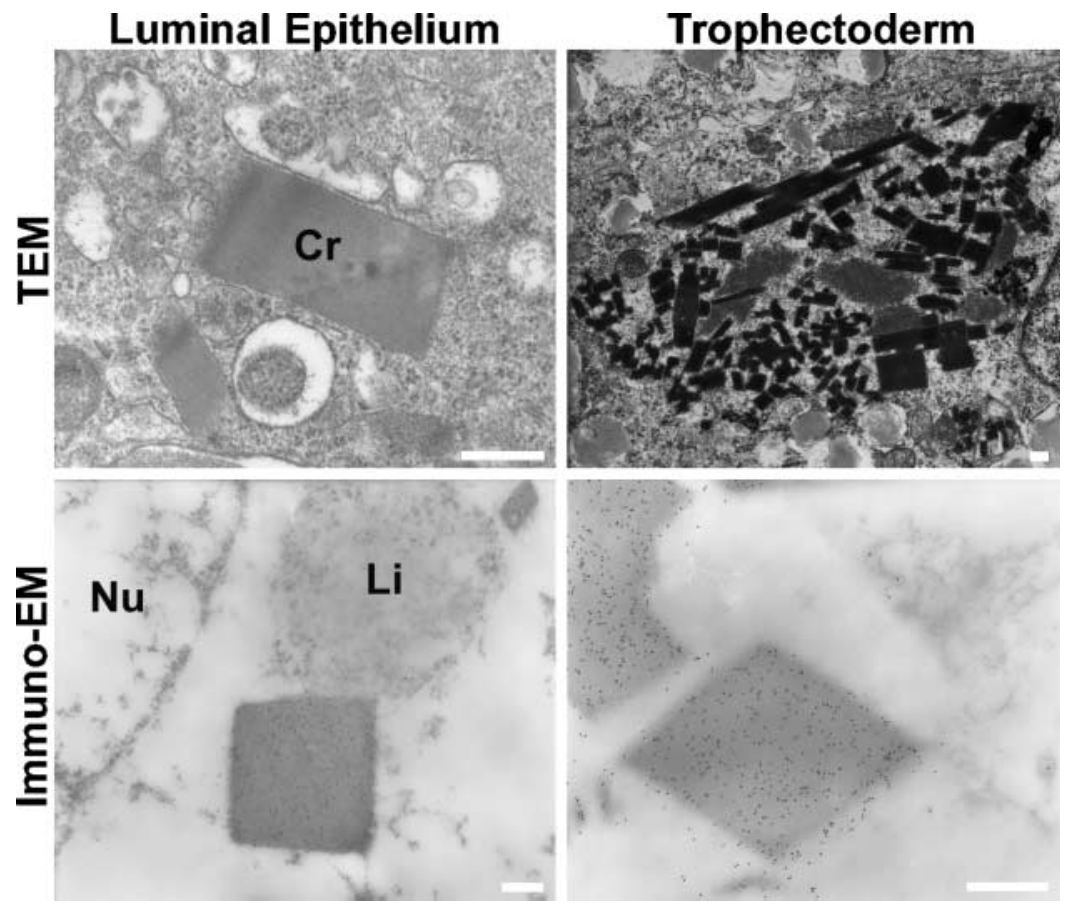

Figure 2 Structural analysis and galectin-15 localization in endometrial LE and conceptus trophectoderm. Cross-sections of endometrium and filamentous conceptus collected on gestational day 16 were analyzed via TEM. Crystalline structures were present in both the endometrial LE and trophectoderm. Galectin-15 protein in the cells was visualized by immunogold TEM (immunogold-EM) using a rabbit anti-ovine galectin-15 antibody. Immunoreactive galectin-15 was localized to these crystals as indicated by the gold labeling. $\mathrm{Nu}$, nucleus; Cr, crystal protein; Li, lipid. Scale bar, $0.1 \mu \mathrm{m}$.

galectin-15 mRNA was detected in both the LE and sGE of the intercaruncular endometrium. Galectin-15 mRNA was not detected in the caruncular or cotyledonary areas of the placentomes (data not shown).

Immunoreactive galectin-15 was detectable at the fetal-maternal interface throughout gestation (Fig. 5). On day 40 of pregnancy, galectin-15 was observed at the apical surface of the sGE. By day 60, galectin-15 protein was observed on the LE as well as within the overlying trophectoderm of the chorion. This spatial pattern of expression was consistent throughout the latter portion of pregnancy.

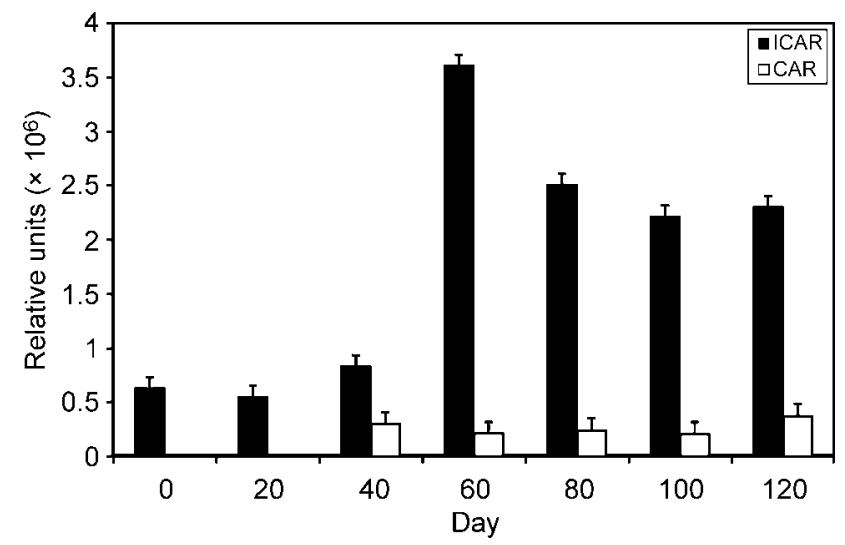

Figure 3 Steady-state levels of galectin-15 mRNA in the intercaruncular (ICAR) and caruncular (CAR) endometrium during pregnancy as determined by slot-blot hybridization analysis. Data are presented as relative units (least-squares means \pm S.E.). Galectin-15 mRNA levels increased after day 40 of pregnancy $(P<0.001$, quadratic effect of day).
Galectin-15 protein was undetectable in the caruncular or cotyledonary areas of the placentomes (data not shown).

Immunoreactive galectin-15 was detectable in allantoic fluid throughout gestation. In the allantoic fluid, galectin15 appeared as a single immunoreactive protein of approximately $15 \mathrm{kDa}$ in size, as analyzed by SDS/PAGE under reducing and denaturing conditions (Fig. 6). Galectin-15 protein was not detectable in amniotic fluid on any day of gestation (data not shown).

\section{Galectin-15 mRNA in the postpartum uterus}

In postpartum ewes (study 3), steady-state levels of galectin-15 mRNA tended to be highest on PPD 1 and decreased through PPD 28 (linear effect of day, $P=0.08$; Fig. 7A). In study 3, galectin-15 mRNA was localized primarily to the LE during the postpartum period, with low expression also detected in the SGE (Fig. 7). On PPD 1, galectin-15 mRNA expression was variable, ranging from high to moderate or low abundance depending on the ewe. The pattern of galectin-15 expression in the LE was variegated, particularly on PPDs 1 and 7. Expression of galectin-15 mRNA was still detected in some areas of the LE on PPD 28.

\section{Discussion}

Available results indicate that the galectin-15 gene is expressed in the endometrial LE and SGE of the intercaruncular endometrium of the pregnant ovine uterus from day 12 to term, encompassing the periods of implantation and placentation, as well as during uterine involution after parturition. In cyclic and early pregnant ewes, galectin-15 


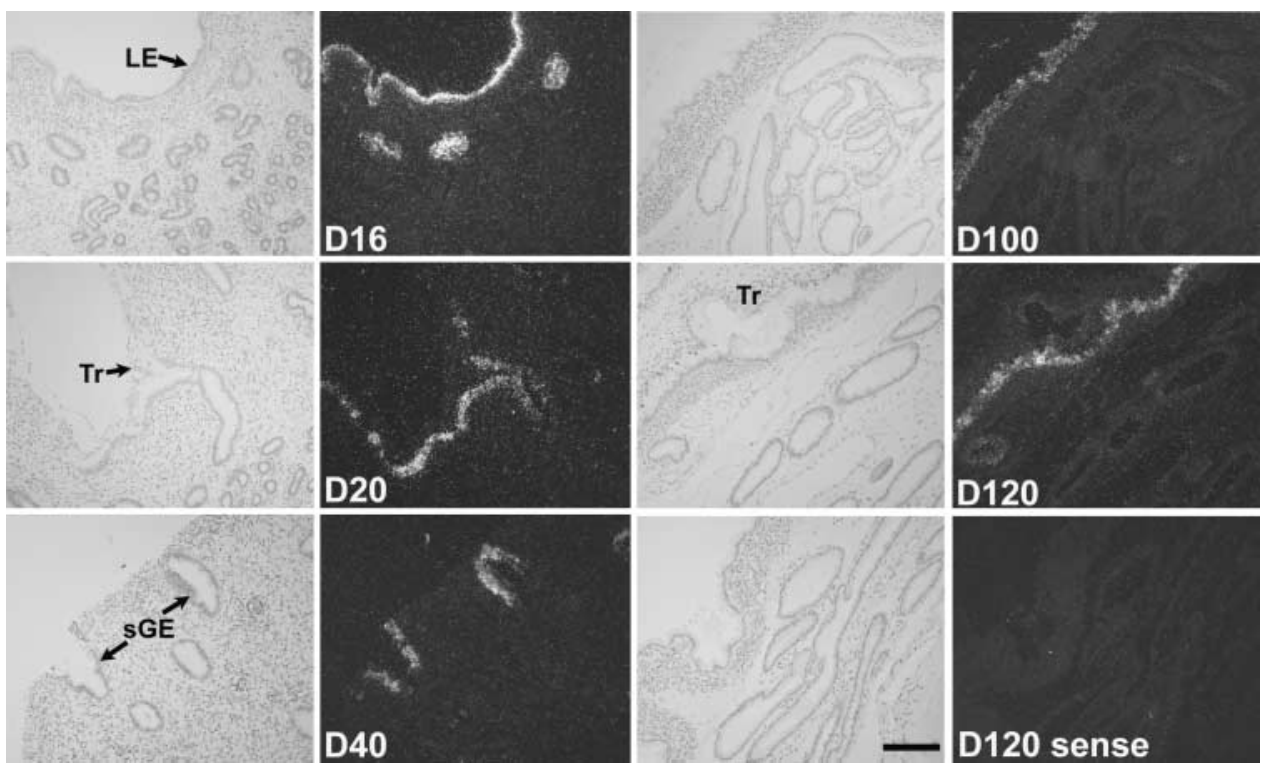

Figure 4 In situ hybridization analysis of galectin-15 mRNA expression in the intercaruncular areas of the endometrium from the uterus of pregnant ewes. Cross-sections of the uterine wall were hybridized with radiolabeled antisense or sense galectin-15 cRNA probes. Hybridized sections were digested with RNase A, and protected transcripts were visualized by liquid emulsion autoradiography. Developed slides were counterstained lightly with hematoxylin, and photomicrographs were taken under brightfield or darkfield illumination. Expression of galectin-15 mRNA was detected only in the endometrial LE and sGE. D, day; Tr, trophectoderm. Scale bar, $100 \mu \mathrm{m}$.

mRNA was also confined to the endometrial LE and sGE after day 10 (Gray et al. 2004). In that study, progesterone induced and interferon $\tau$ stimulated galectin-15 gene expression in the endometrium. In the present study, analysis of galectin-15 in uterine flushes indicated that secreted extracellular galectin-15 is in a multimeric form, particularly as the amount of galectin-15 mRNA increases in the endometrial LE and SGE and galectin-15 protein increases in the uterine lumen on days 14 and 16 of pregnancy (Gray et al. 2004). Other galectin family members are known to homodimerize and form multimers (Cho \& Cummings 1996, Yang et al. 1998, Dunphy et al. 2002). The effects of galectin multimerization on biological function are not well understood, particularly in regard to ability of galectins to bind to glycoproteins and/or glycolipid receptors and initiate biological responses.

Immunogold electron microscopy revealed that within the endometrial LE and conceptus trophectoderm, galectin-15 protein was localized to large, membrane-bound rhomboidal crystal structures. The working hypothesis is that galectin-15 protein forms crystals within the endometrial LE and is also secreted into the uterine lumen as a part of histotroph. The conceptus trophectoderm then absorbs extracellular galectin-15 in the uterine histotroph, wherein it becomes a component of intracellular crystals as originally described for the $14 \mathrm{kDa}$ protein, e.g. galectin-15, by Kazemi and coworkers (Kazemi et al. 1990). In the ovine conceptus trophectoderm, crystals were found to increase in number and size between days 10 and 18 of pregnancy (Wintenberger-Torres \& Flechon 1974). The presence of crystals in sheep uterine histotroph (or uterine milk), present between maternal and fetal intercotyledonary membranes, is well documented (Wimsatt 1951, Hoffman \& Olson 1984). Progesterone-induced crystal structures in the endometrium and/or conceptus trophectoderm have been described in the sheep (WintenbergerTorres \& Flechon 1974, Hoffman \& Olson 1984, Kazemi et al. 1990), mouse (Calarco \& Szollosi 1973), rabbit (Nakoa et al. 1971, Daniel \& Kennedy 1978) and human (Nakoa et al. 1971). Although the biological role(s) of galectin-15 crystals in the uterine epithelia is not known, the intracellular role of other galectins include modulation of cell growth, differentiation and apoptosis through functioning as pre-mRNA splicing factors and interacting with specific intracellular ligands such as Ras and Bcl-2 (Hernandez \& Baum 2002, Liu et al. 2002).

During synepitheliochorial placentation in sheep, trophoblast giant BNCs begin to differentiate between days 14 and 16 and then fuse apically with the endometrial LE and form syncytia, thereby assimilating and replacing the endometrial LE (Wimsatt 1951, Wooding 1984). In the intercaruncular endometrium, the LE reappears between days 40 and 60 of pregnancy, and this was associated with an increase in galectin-15 mRNA in the intercaruncular endometrium in the present study. Galectin-15 mRNA and protein expression was not observed in the placentomes, which are comprised of placental cotyledons and endometrial caruncles devoid of LE. Although the placenta is expelled shortly after parturition, regrowth of the entire LE covering the endometrial caruncules takes at least 4 weeks during postpartum involution of the uterus (Gray et al. 2003). The expression of galectin-15 mRNA in 

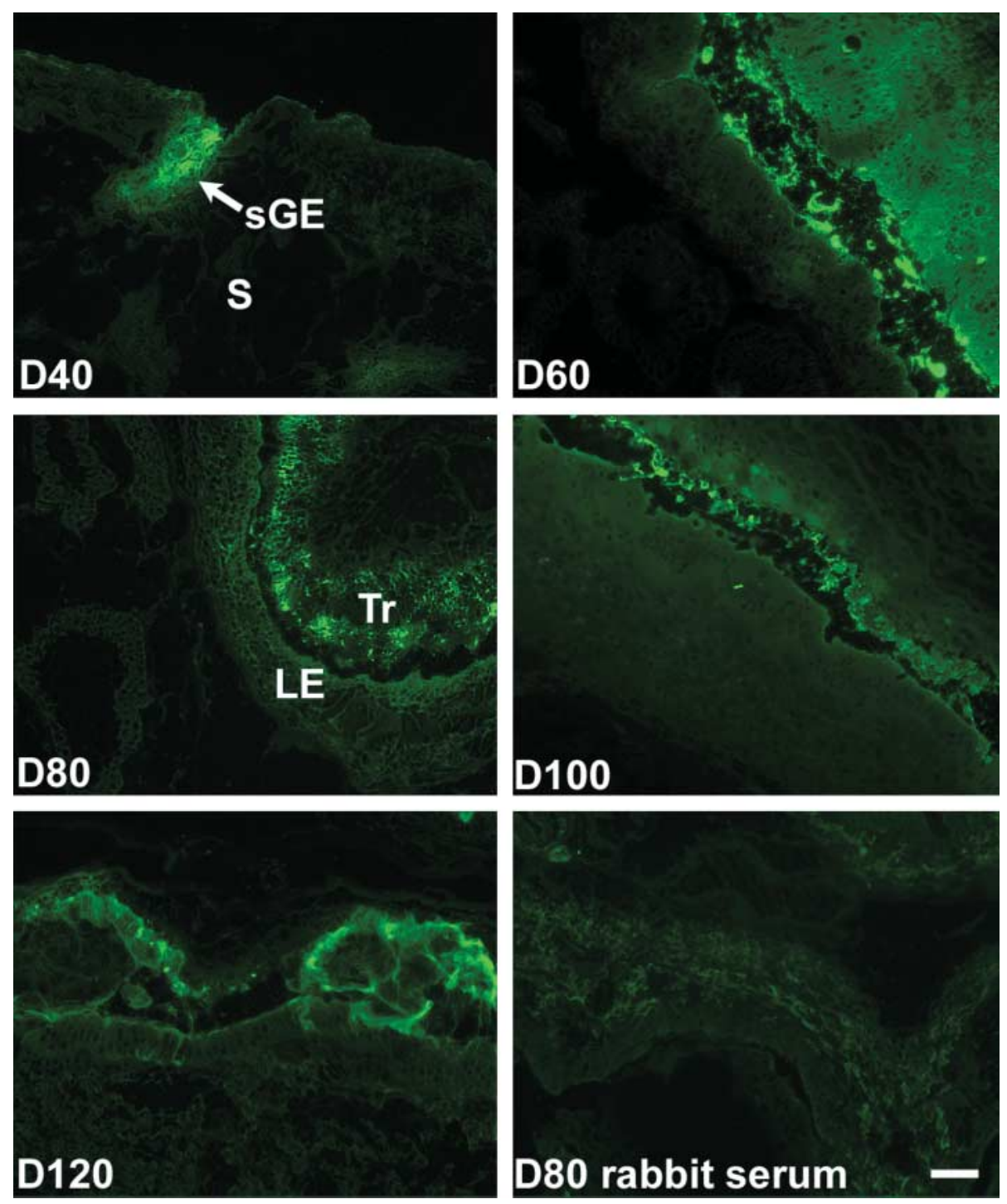

Figure 5 Immunofluorescence localization of galectin- 15 protein in the intercaruncular areas of the endometrium from uteri of pregnant ewes on days (D) 40, 60, 80, 100 and 120. Galectin-15 protein was observed predominantly in the conceptus trophectoderm and, to a lesser extent, in the endometrial LE and sGE. S, stroma; Tr, trophectoderm. Scale bar, $50 \mu \mathrm{m}$.

the epithelia is variegated during the postpartum period and steady-state levels declined slowly over the month following parturition. This unique expression pattern suggests that the phenotype of the endometrial epithelia is changing rapidly during uterine involution.

Although galectin-15 mRNA was found exclusively in the endometrial LE and SGE of the uterus, immunoreactive galectin-15 protein was detected predominantly in the chorion/trophectoderm of the placenta as well as in the allantoic fluid. Galectin-15 protein is present in the uterine lumen of early pregnant ewes as well as in uterine milk recovered from the non-gravid horn of unilaterally pregnant ewes (Gray et al. 2004). Other galectin family members also exhibit dual localization, being found in both extracellular (cell-surface and medium) and intracellular (cytoplasm and, in some cases, the nucleus) compartments (Hughes 1997). Although galectins are often present on cell surfaces or in the extracellular matrix, galectins lack a classical secretion signal sequence and are secreted by a novel apocrine mechanism that does not involve the endoplasmic reticulum-Golgi pathway (Hughes 1999, Boulianne et al. 2000). Similarly, ovine galectin-15 lacks a signal peptide (Dunphy et al. 2000, Gray et al. 2004). After implantation, the chorioallantois develops unique structures, termed areloae, that develop over the mouth of each uterine gland as specialized areas for absorption and transport of uterine histotroph into the conceptus (Bazer 1975). These results support the idea that galectin-15 protein is synthesized by the endometrial LE and SGE and then secreted into the uterine lumen, where it is absorbed by the placenta, transported into the fetal circulation, and cleared by the kidney into the allantois via the urachus (Bazer 1975, Roberts \& Bazer 1988). Although the allantois was initially considered a reservoir for waste products of the fetus, it serves to store most secreted proteins from the endometrium (Bazer et al. 


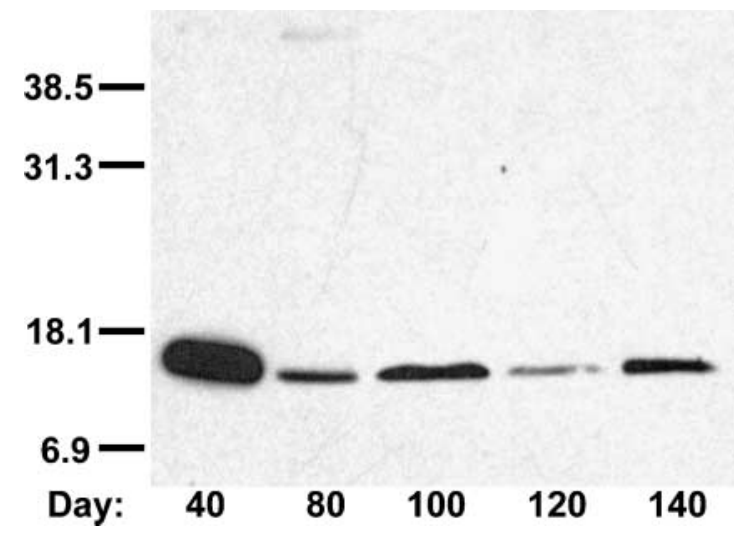

Figure 6 Analysis of immunoreactive galectin-15 protein in the allantoic fluid of pregnant ewes. Allantoic fluid proteins were separated under reducing conditions. Western-blot analysis found a single immunoreactive protein of $\sim 15 \mathrm{kDa}$ in all allantoic fluid samples. Positions of prestained molecular-mass standards $\left(\times 10^{-3}\right)$ are indicated on the left.
1975, Moffatt et al. 1987). In contrast, amniotic fluid is not in the path for protein clearance by the fetal kidney and, therefore, does not function in this capacity. In the present study, galectin-15 protein was not detected in amniotic fluid, but was present in allantoic fluid where it may simply serve as a source of amino acids for fetal and placental growth and function or possess other biological functions. During human pregnancy, galectin-13 (or placental protein-13) plays a role in calcium-mediated depolarization, liberation of arachidonic acid and the formation of thromboxane in the placenta (Burger et al. 2004). Indeed, a reduction in galectin-13 is associated with intrauterine growth retardation (Burger et al. 2004).

Another potential biological function of endometrial galectin-15 throughout pregnancy and during involution may be to modulate inflammatory and immune responses. Under the influence of progesterone, uterine lymphocyte dynamics and functions are altered that inhibit maternal responses to the fetal-placental semi-allograft which is critical for pregnancy success (Clark et al. 1999). As in other mammals, the ovine uterus has pregnancy-associ-

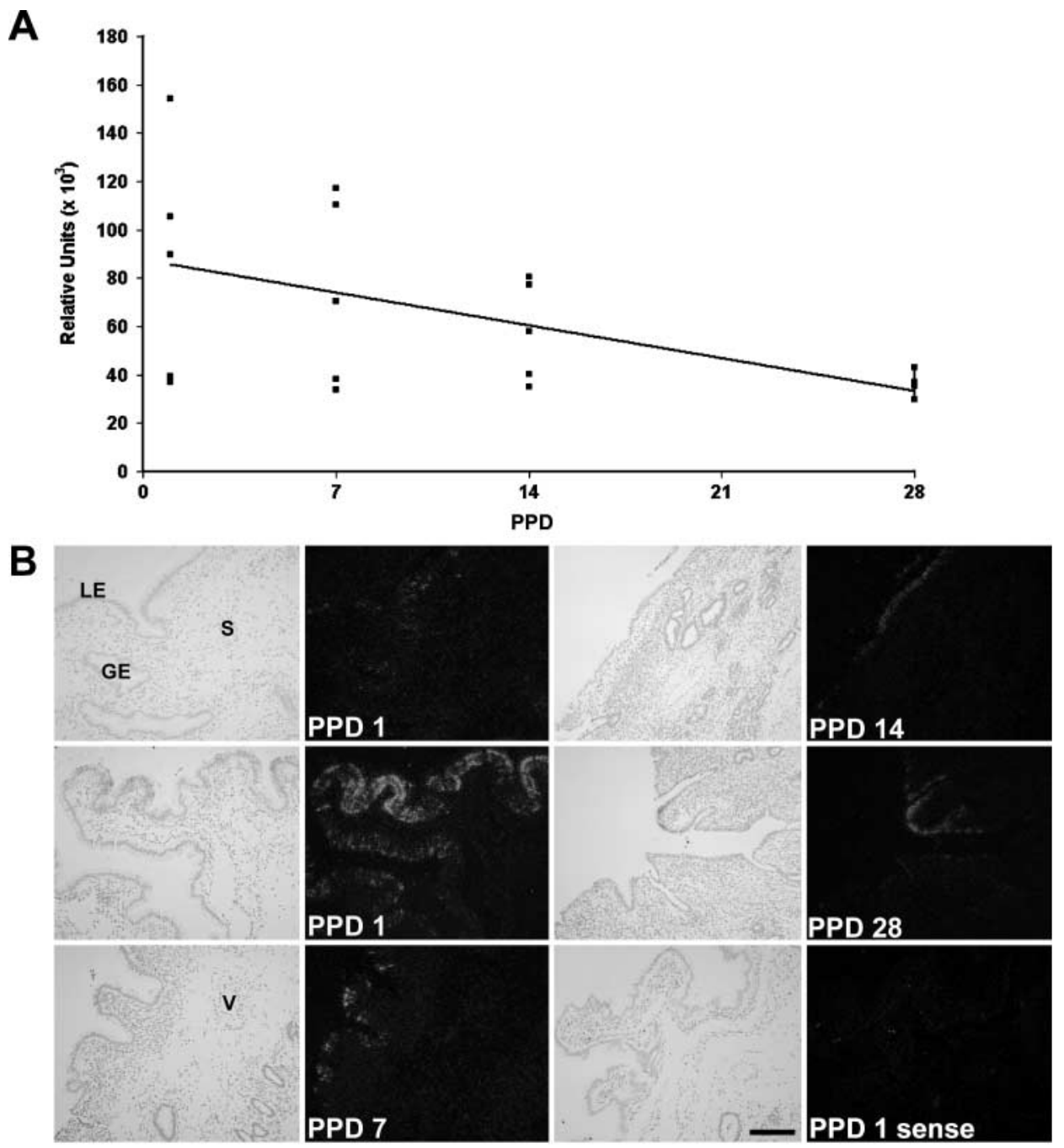

Figure 7 Spatial and temporal patterns of galectin-15 mRNA expression during the postpartum period. (A) Steady-state levels of galectin-15 mRNA in the endometrium during the postpartum period as determined by slot-blot hybridization analysis. Data are presented as least-squares means \pm S.E. Galectin-15 mRNA levels declined after parturition $(P=0.08$, linear effect of day). (B) In situ hybridization analysis of galectin-15 mRNA expression in the intercaruncular areas of the endometrium of the postpartum ovine uterus. Cross-sections of the uterine wall were hybridized with radiolabeled antisense or sense cRNA probes generated from linearized plasmid cDNA clones. Hybridized sections were digested with RNase A, and protected transcripts were visualized by liquid emulsion autoradiography. Developed slides were counterstained lightly with hematoxylin, and representative photomicrographs were taken under brightfield or darkfield illumination. Expression of galectin-15 mRNA was detected only in the endometrial LE and sGE. S, stroma; V, blood vessel. Scale bar, $100 \mu \mathrm{m}$. 
ated changes in lymphocytes, macrophages and natural killer cells which are differentially regulated by conceptus and maternal factors (Gogolin-Ewens et al. 1989, Lee et al. 1992, Fox et al. 1998, Tekin \& Hansen 2002, 2004). Evidence suggests that progesterone stimulates the endometrium to induce synthesis of regulatory molecules that affect lymphocyte dynamics (Majewski et al. 2001). A progesterone-stimulated immunoregulatory protein family is the uterine serpins or uterine milk proteins (Leslie \& Hansen 1991, Hansen 1998). Similarly, galectin-15 is also induced by progesterone and a component of uterine milk (Gray et al. 2004). Interestingly, galectin-15 was originally found to be induced in gastrointestinal tissue and secreted into the intestinal lumen in response to inflammation and eosinophil infiltration after infection of sheep with the helminth, Haemonchus contortus (Dunphy et al. 2000). Given that several other galectins regulate innate and adaptive immune responses (Rabinovich et al. 2002, Young \& Meeusen 2004), one may speculate that galectin15 in the ovine endometrium is another progesteroneinduced immunoregulatory factor that modulates the maternal intrauterine immune system, thereby protecting the conceptus and promoting placental growth, which is a process strikingly similar to host-parasite interactions (Guimond et al. 1999). Future experiments will assess the intracellular and extracellular role(s) of galectin-15 in regulation of uterine immune responses, placental morphogenesis and function, and fetal growth.

\section{Acknowledgements}

The authors thank Fuller W Bazer for helpful discussion, members of the laboratory for assistance with animal husbandry and surgery, and Dr Els N T Meeusen (Monash University, Melbourne, Australia) for the gift of rabbit anti-ovine galectin15 antibody. This work was supported by USDA NRI grant 2001-02259 and NIEHS P30ES09106. The authors declare that there is no conflict of interest that would prejudice the impartiality of this scientific work.

\section{References}

Alexander G \& Williams D 1968 Hormonal control of amniotic and allantoic fluid volume in ovariectomized sheep. Journal of Endocrinology 41 477-485.

Bazer FW 1975 Uterine protein secretions: Relationship to development of the conceptus. Journal of Animal Science 41 1376-1382.

Bazer FW 1989 Allantoic fluid: regulation of volume and composition. In Reproductive and Perinatal Medicine. Vol. 11: Fetal and Neonatal Body Fluids, pp 135-155. Eds RA Brace, MG Ross \& JE Robillard. Ithaca: Perinatology Press.

Bazer FW, Chen TT, Knight JW, Schlosnagle D, Baldwin NJ \& Roberts RM 1975 Presence of a progesterone-induced, uterine specific, acid phosphatase in allantoic fluid of gilts. Journal of Animal Science $\mathbf{4 1}$ 1112-1119.

Boulianne RP, Liu Y, Aebi M, Lu BC \& Kues U 2000 Fruiting body development in Coprinus cinereus: regulated expression of two galectins secreted by a non-classical pathway. Microbiology 146 $1841-1853$.

Burger O, Pick E, Zwickel J, Klayman M, Meiri H, Slotky R, Mandel S, Rabinovitch L, Paltieli Y \& Admon A et al. 2004 Placental pro- tein 13 (PP-13): effects on cultured trophoblasts, and its detection in human body fluids in normal and pathological pregnancies. Placenta 25 608-622.

Calarco PG \& Szollosi D 1973 Intracisternal A particles in ova and preimplantation stages of the mouse. Nature New Biology 243 91-93.

Carson DD, Bagchi I, Dey SK, Enders AC, Fazleabas AT, Lessey BA \& Yoshinaga K 2000 Embryo implantation. Developmental Biology 223 217-237.

Cho M \& Cummings RD 1996 Characterization of monomeric forms of galectin-1 generated by site-directed mutagenesis. Biochemistry $3513081-13088$.

Choi $\mathrm{Y}$, Johnson GA, Burghardt RC, Berghman LR, Joyce MM, Taylor KM, Stewart MD, Bazer FW \& Spencer TE 2001 Interferon regulatory factor-two restricts expression of interferon- stimulated genes to the endometrial stroma and glandular epithelium of the ovine uterus. Biology of Reproduction 65 1038-1049.

Clark DA, Arck PC \& Chaouat G 1999 Why did your mother reject you? Immunogenetic determinants of the response to environmental selective pressure expressed at the uterine level. American Journal of Reproductive Immunology 41 5-22.

Cooper DN 2002 Galectinomics: finding themes in complexity. Biochimica et Biophysica Acta 1572 209-231.

Daniel JC Jr \& Kennedy JR 1978 Crystalline inclusion bodies in rabbit embryos. Journal of Embryology and Experimental Morphology 44 31-43.

Dunphy JL, Balic A, Barcham GJ, Horvath AJ, Nash AD \& Meeusen EN 2000 Isolation and characterization of a novel inducible mammalian galectin. Journal of Biological Chemistry 275 32106-32113.

Dunphy JL, Barcham GJ, Bischof RJ, Young AR, Nash A \& Meeusen EN 2002 Isolation and characterization of a novel eosinophilspecific galectin released into the lungs in response to allergen challenge. Journal of Biological Chemistry 277 14916-14924.

Fazleabas AT, Donnelly KM, Hild-Petito S, Hausermann HM \& Verhage HG 1997 Secretory proteins of the baboon (Papio anubis) endometrium: regulation during the menstrual cycle and early pregnancy. Human Reproduction Update 3 553-559.

Fox A, Lee CS, Brandon MR \& Meeusen EN 1998 Effects of pregnancy on lymphocytes within sheep uterine interplacentomal epithelium. American Journal of Reproductive Immunology $\mathbf{4 0}$ 295-302.

Gogolin-Ewens KJ, Lee CS, Mercer WR \& Brandon MR 1989 Site-directed differences in the immune response to the fetus. Immunology 66 312-317.

Gray CA, Taylor KM, Ramsey WS, Hill JR, Bazer FW, Bartol FF \& Spencer TE 2001 Endometrial glands are required for preimplantation conceptus elongation and survival. Biology of Reproduction $641608-1613$.

Gray CA, Burghardt RC, Johnson GA, Bazer FW \& Spencer TE 2002 Evidence that absence of endometrial gland secretions in uterine gland knockout ewes compromises conceptus survival and elongation. Reproduction 124 289-300.

Gray CA, Stewart MD, Johnson GA \& Spencer TE 2003 Postpartum uterine involution in sheep: histoarchitecture and changes in endometrial gene expression. Reproduction 125 185-198.

Gray CA, Adelson DL, Bazer FW, Burghardt RC, Meeusen EN \& Spencer TE 2004 Discovery and characterization of an epithelialspecific galectin in the endometrium that forms crystals in the trophectoderm. PNAS $1017982-7987$.

Guimond M, Wang B \& Croy BA 1999 Immune competence involving the natural killer cell lineage promotes placental growth. Placenta 20 441-450.

Hansen PJ 1998 Regulation of uterine immune function by progesterone-lessons from the sheep. Journal of Reproductive Immunology $4063-79$.

Hernandez JD \& Baum LG 2002 Ah, sweet mystery of death! Galectins and control of cell fate. Glycobiology 12 127R-136R.

Hoffman LH \& Olson GE 1984 Crystalline inclusions in embryonic and maternal cells. In Ultrastructure of Reproduction, pp 
235-246. Eds J van Blerkom \& PM Motta. Boston: Martinus Nijhoff Publishers.

Hughes RC 1997 The galectin family of mammalian carbohydratebinding molecules. Biochemical Society Transactions 25 $1194-1198$.

Hughes RC 1999 Secretion of the galectin family of mammalian carbohydrate-binding proteins. Biochimica et Biophysica Acta $1473172-185$.

Johnson GA, Burghardt RC, Spencer TE, Newton GR, Ott TL \& Bazer FW 1999 Ovine osteopontin: II. Osteopontin and alpha(v)beta(3) integrin expression in the uterus and conceptus during the periimplantation period. Biology of Reproduction 61 892-899.

Kane MT, Morgan PM \& Coonan C 1997 Peptide growth factors and preimplantation development. Human Reproduction Update $\mathbf{3}$ 137-157.

Kazemi M, Amann JF, Keisler DH, Ing NH, Roberts RM, Morgan G \& Wooding FBP 1990 A progesterone-modulated, low-molecularweight protein from the uterus of the sheep is associated with crystalline inclusion bodies in uterine epithelium and embryonic trophectoderm. Biology of Reproduction 43 80-96.

Kwon H, Wu G, Meininger CJ, Bazer FW \& Spencer TE 2004 Developmental changes in nitric oxide synthesis in the ovine placenta. Biology of Reproduction 70 679-686.

Lee CS, Meeusen E, Gogolin-Ewens K \& Brandon MR 1992 Quantitative and qualitative changes in the intraepithelial lymphocyte population in the uterus of nonpregnant and pregnant sheep. American Journal of Reproductive Immunology 28 90-96.

Leslie MV \& Hansen PJ 1991 Progesterone-regulated secretion of the serpin-like proteins of the ovine and bovine uterus. Steroids $\mathbf{5 6}$ 589-597.

Liu FT \& Rabinovich GA 2005 Galectins as modulators of tumour progression. Nature Reviews Cancer 5 29-41.

Liu FT, Patterson RJ \& Wang JL 2002 Intracellular functions of galectins. Biochimica et Biophysica Acta 1572 263-273.

Majewski AC, Tekin S \& Hansen PJ 2001 Local versus systemic control of numbers of endometrial T cells during pregnancy in sheep. Immunology 102 317-322.

Moffatt RJ, Bazer FW, Roberts RM \& Thatcher WW 1987 Secretory function of the ovine uterus: effects of gestation and steroid replacement therapy. Journal of Animal Science 65 1400-1410.

Nakoa K, Meyer CJ \& Noda Y 1971 Progesterone-specific protein crystals in the endometrium: an electron microscopic study. American Journal of Obstetrics and Gynecology 111 1034-1038.

Rabinovich GA, Rubinstein N \& Fainboim L 2002 Unlocking the secrets of galectins: a challenge at the frontier of glyco-immunology. Journal of Leukocyte Biology $71741-752$.

Reynolds E 1963 The use of lead citrate at high $\mathrm{pH}$ as an electronopaque stain in electron microscopy. Journal of Cell Biology 17 208-212.
Roberts RM \& Bazer FW 1988 The functions of uterine secretions. Journal of Reproduction \& Fertility 82 875-892.

Roberts RM, Murray MK, Burke MG, Ketcham CM \& Bazer FW 1987 Hormonal control and function of secretory proteins. Advances in Experimental and Medical Biology 230 137-150.

Spencer TE, Johnson GA, Bazer FW \& Burghardt RC 2004 Implantation mechanisms: insights from the sheep. Reproduction $\mathbf{1 2 8}$ $657-668$.

Spencer TE, Bartol FF, Bazer FW, Johnson GA \& Joyce MM 1999a Identification and characterization of glycosylation-dependent cell adhesion molecule 1-like protein expression in the ovine uterus. Biology of Reproduction $60241-250$.

Spencer TE, Gray A, Johnson GA, Taylor KM, Gertler A, Gootwine E, Ott TL \& Bazer FW $1999 b$ Effects of recombinant ovine interferon tau, placental lactogen, and growth hormone on the ovine uterus. Biology of Reproduction 61 1409-1418.

Tekin S \& Hansen PJ 2002 Natural killer-like cells in the sheep: functional characterization and regulation by pregnancy-associated proteins. Experimental Biology and Medicine (Maywood, NJ) 227 803-811.

Tekin S \& Hansen PJ 2004 Regulation of numbers of macrophages in the endometrium of the sheep by systemic effects of pregnancy, local presence of the conceptus, and progesterone. American Journal of Reproductive Immunology 51 56-62.

Wimsatt WA 1951 Observations of the morphogenesis, cytochemistry and significance of the binucleate giant cells of the placenta of ruminants. Journal of Anatomy 89 233-282.

Wintenberger-Torres S \& Flechon JE 1974 Ultrastructural evolution of the trophoblast cells of the pre-implantation sheep blastocyst from day 8 to day 18. Journal of Anatomy $118143-153$.

Wooding FB 1984 Role of binucleate cells in fetomaternal cell fusion at implantation in the sheep. American Journal of Anatomy $\mathbf{1 7 0}$ $233-250$.

Yang RY \& Liu FT 2003 Galectins in cell growth and apoptosis. Cellular and Molecular Life Science $60267-276$.

Yang RY, Hill PN, Hsu DK \& Liu FT 1998 Role of the carboxyl-terminal lectin domain in self-association of galectin-3. Biochemistry 37 4086-4092.

Young AR \& Meeusen EN 2004 Galectins in parasite infection and allergic inflammation. Glycoconjugate Journal 19 601-606.

Received 27 December 2004

First decision 28 January 2005

Revised manuscript received 17 March 2005

Accepted 9 May 2005 